\title{
Forensic Accounting and Fraud Prevention and Detection in Nigerian Banking Industry
}

\author{
Ogundana Oyebisi, Okere Wisdom*, Ogunleye Olusogo and Oladapo Ifeoluwa \\ Department of Accounting, Bells University of Technology, Nigeria \\ *Corresponding author: Okere Wisdom, Department of Accounting, Bells University of Technology, Ota, Ogun State, Nigeria
}

Submission: 㘹 May 21, 2018; Published: 些 May 31, 2018

\begin{abstract}
This study examined the role of the forensic accountant in the prevention and detection of fraud in the Nigeria banking sector. The study adopted the Survey research design while the source of data is the primary data and the data sourced was gleened from copies of the questionnaire administered to selected banks. Three (3) hypotheses were formulated and tested using Simple regression at a significant level of 5\%, Independent T-test and Oneway Anova. Findings revealed a negative significant relationship between IFRS adoption and foreign direct investment of Nigeria banks. Findings also revealed that between forensic accounting has a significant impact on fraud prevention and detection. In addition, the findings of this study also revealed that there is a low level of the awareness of forensic accounting in the Nigeria banking industry. Consequently, the study recommended that Nigerian Government should provide the enabling environment for forensic accounting profession to thrive in the country by strengthening the legal, educational and political frame work in the country.
\end{abstract}

Keywords: Auditing; Detection; Fraud; Forensic; Prevention; Investigation

Abbreviations: CBN: Central Bank of Nigeria; BOFIA: Banks and Other Financial Institutions; EFCC: Economic and Financial Crimes Commission; ICPC: Independent Corrupt Practices Commission; GAAP: Generally Accepted Accounting Principles; OLS: Ordinary Least Square Regression; SPSS: Statistical Package for Social Sciences; NUC: National Universities Commission; ICAN: Institute of Chartered Accountants of Nigeria

\section{Introduction}

The Nigeria banking sector is composed of deposit money banks, development banks, merchant banks and the Central Bank of Nigeria (CBN), which is the apex bank. The apex bank is charged with the responsibility of administering the Banks and Other Financial Institutions (BOFIA) Act 1991 as amended, with the sole aim of ensuring high standard of banking practice and financial stability through its surveillance activities as well as the promotion of an efficient payment system, [1]. Among the Nigerian Industrial sectors today, one can say that the banking industry is the most visible and arouses the most public interest. According to Adeyemo [2], "the banking sector plays a vital role of provision of an efficient payment system, financial intermediation and facilitation of the implementation of monetary policies". Banks have been identified as an engine of growth in the economy because they perform resource allocation function by mobilizing and channeling resources from surplus economic unit to deficit unit. The relevance of banks in the economy of any nation cannot be overemphasized. They are the cornerstones, the linchpin of the economy of every country. Consequently, it is submitted that the economic well-being of a nation is a function of advancement and development of her banking industry.
In today's Nigeria banking sector, hundreds of Billions of Naira get squandered yearly due to bank fraud [2]. The incidence of fraud continues to increase across the banking sector and across nations, and controlling fraud in the banking sector is a major task for all the stake holders in the sector. Fraud is a universal problem as no nation is immuned, though developing countries like Nigeria and their various states suffer the most pain. Although the incidence of fraud is neither limited to the banking industry nor to the Nigerian economy, high rates of fraud within the banking industry calls for urgent attention with a view to finding lasting solutions. The involvement of the banking industry in Nigeria has brought about loss of confidence among the banking public and impeded the going concern status of several banks in the country. The Association of Certified Fraud Examiners [3] defines fraud as "any illegal acts characterized by deceit, concealment or violation of trust. These acts are not dependent on the application of threat of violence or of physical force".

Despite the establishment of anti-fraud agencies like Economic and Financial Crimes Commission (EFCC) and Independent Corrupt Practices Commission (ICPC), cases of fraud practices in the banking sector appears to be on the increase and it seems difficult 
for these anti-fraud agencies to successfully prosecute many of the alleged cases of fraud involving billions of naira. Most of these fraudulent practices are perpetrated by highly skilled fraudsters, employing sophisticated methods, thus requiring highly skilled and capable individuals to undo the fraudulent schemes. There is a need to respond to this criminal threat and the skill of non-traditional investigator like accountant and legal expertise are needed to combat these corporate ills by highly skilled fraudsters. The failure of statutory audit to prevent and reduce misappropriation of corporate fund and prevent increase in corporate crime has put pressure on the professional accountant and legal practitioner to find a better way of minimizing fraud in banking industry. This is where the role of forensic accounting in fraud prevention and detection comes in to bridge the gap in banking sector in other to curb financial crimes.

Forensic accounting according to Crumbley et al. [4] is the action of identifying, recording, settling, extracting, sorting, reporting and verifying past financial data or other accounting activities, for settling current or prospective legal disputes, or using such past financial data for projecting future financial data to settle legal disputes. It utilizes accounting, auditing and investigative skills when conducting any kind of investigation. This study therefore examines the role of the Forensic Accountants in the prevention and detection of fraud in the Nigeria banking industry. The rest of this study is divided as follows: Section 2 contains the review of extant literature. Section 3 contains the research methods of the study. Section 4 reveals the analysis of the result while Section 5 conclusion and recommendation of the research study.

\section{Literature Review}

\section{Concept of forensic accounting}

Accounting today is called the language of business this is so because it is the vehicle for reporting financial information about a business entity to many different groups of people. There are different branches of accounting. The branch of accounting that concentrates on reporting to people inside the business entity is called management accounting. It is used to provide information to employees, managers, owner-managers and auditors. Management accounting is concerned primarily with providing a basis for making management or operating decisions. Accounting that provides information to people outside the business entity is called financial accounting. It provides information to present and potential shareholders, creditors such as banks or vendors, financial analysts, economists, and government agencies. Because these users have different needs, the presentation of financial accounts is very structured and subject to many more rules than management accounting. The body of rules that governs financial accounting is called Generally Accepted Accounting Principles (GAAP) [5].

Forensic accounting also called investigative accounting or fraud audit is a merger of forensic science and accounting [6]. Forensic science, as Crumbley [7] put it may be defined as application of laws of nature to the laws of man. A forensic scientist is one who examines and interprets evidence and facts in legal cases and also offers expert opinions regarding their findings in the court of law. In the present context, the science is accounting, hence the examination and interpretation will be of economic financial information. According to Bologna et al. [8], forensic and investigative accounting is the use of financial skills and investigative mentality to unresolved issues, applied within the context of the rules of evidence. Zysman [9] defined forensic accounting as integration of accounting, auditing and investigative skills. Other definitions have been given by Joshi [10], Mehta et al. [11] and Crumbley [12]. Coenen [13] avers that forensic accounting uses accounting concepts and techniques in solving legal problems. Evazzadeh et al. [14] consider forensic accounting as a specialized field in accounting frequently concerned with legal problems and complaints.

Nevertheless, there is no generally acceptable definition of forensic accounting. There may be so many definitions of forensic accounting as there are authors. But the Association of Certified Fraud Examiners [3] defined forensic accounting as the use of skills in potential or real civil or criminal disputes, including generally accepted accounting and auditing principles in establishing losses of profit, income, property or damage, estimations of internal controls, frauds and others that involve inclusion of accounting expertise into the legal system. Hence, forensic accounting involves the application of accounting concepts, auditing techniques and investigative procedures in solving legal problems. Be that as it may, it should be noted here that the responsibility of preventing and detecting fraud in financial statements lies not only in the hands of management of an enterprise, but also other control institutions and mechanisms. System of internal control, internal auditing and audit committee are the key elements for prevention and detection of frauds that are created through property misuse as well as those that use financial statements as instruments of frauds. But external auditing and forensic accounting perform retrospective control of financial data with the aim of detecting omissions, frauds and securing the reliability and credibility of financial statements.

Krstić [15] has noted that it is now being considered as agenerally accepted objective for business activity to secure reliable financial information through disclosing financial statements. Numerous financial frauds have seriously disrupted the trust of many users of financial information contained in financial statements. Generally, forensic accounting demands reporting where accountability of fraud, is established and the report are considered as evidence in the court of law [16]. It provides an accounting analysis that is suitable in the court, which will form the basis of discussion, debate and ultimately dispute resolution. As Mckittrick [17] puts it, "forensic accounting is primarily focused on legal situations but it has the potential to reach beyond the legal focus into operating areas that could be of benefits to any organization", including the banking sector.

\section{What is fraud?}

Literature is replete with various definitions of fraud. It varies between organizations and jurisdictions [18]. Although 
it is not the intention of this research to enter into the debate on definition of fraud as several studies [19-21] have done that, a proper understanding of fraud is necessary to situate the present study. The Association of Certified Fraud Examiners [22] defined fraud as the use of one's occupation for personal enrichment through deliberate misuse or misapplication of the employing organization's resources or assets. It is therefore any act of misappropriation, theft or embezzlement of corporate assets in a particular economic environment. It has been considered as any act of deception performed by somebody to cheat or deceive another person to his detriment or the detriment of any other, or to cause injury or loss to another person while the perpetrator has a clear knowledge of his intension to deceive, falsify or take advantage over the unsuspecting and innocent victim [16] resulting to suffering loss or damage [17].

According to Udoayang et al. [23], fraud is simply "stealing by tricks." Ramamoorti et al. [24] in their definition of fraud argued that it "is a human endeavor, involving deception, purposeful intent, intensity of desire, risk of apprehension, violation of trust and rationalization,". Several authors 0jo et al. [25] in Hamilton et al. [26]; Sydney [27]; Ojigbede [28] agree that a fraudulent activity involves the use of deceit and tricks to change the truth so as to deprive another person of his right. Fraud is any action, behavior or oral expressions deliberately aimed at deception and/ or misinformation. It is a sequence of activities perpetrated to obtain money, property or services, to avoid payment or of services or to secure personal or business advantages. These acts are not dependent upon the application of threat of violence or of physical force (International Standards for Professional Practice of Internal Auditing, 2002) [29].

Pedneault, Sheetz, and Rudewicz, agree that modern definition of fraud appears to be derived from case and statute law even though many of the ancient components still obtain. It can be traced to the Latin noun fraus, which conveys a range of meaning centered on the idea of harm, deceit and wrong doing [30]. "The modern definition derived from case law focuses on the intent of the fraudster(s) to separate the trusting victim from property or a legal right through deception for his or her own benefit" [30]. In any case, all the definitions of fraud stresses on acts that are capable of deceiving and misappropriation perpetrated deliberately. Such acts are carried by somebody or group of persons against another person or an organization, and can be expressed verbally or through behavior.

\section{Forensic accounting and fraud prevention and detection}

There are several empirical studies examining the relationship between forensic accounting and fraud detection and prevention. Many of these studies draw evidence from developed economies like the United States of America, the United Kingdom and Canada. In Nigeria, few studies have also been conducted to investigate Forensic accounting and fraud prevention and detection, especially to examine their relevance to financial crimes in banks, public sector and private corporate organizations. Kasum [5] examined the relevance of forensic accountant to financial crimes in third world economies. The study specifically investigated the extent of financial crimes in Nigeria and compares the private and public sector with the view of determining the sector where the service of forensic accountants is more required. The study employed both primary and secondary data and they were analyzed using the descriptive statistics and regression or sensitivity method of analysis. The result showed that forensic accountants and their services are required for fraud and corruption related issues in Nigeria. However, the results for private sector were not statistically significant. Based on findings, the study concluded that although forensic accountants have roles to play generally, but more in the public sector. The study therefore recommended the strengthening of forensic accounting institutions and utilization of their services in public sector of developing nation economies.

Arising from the increasing fraudulent practices across organizations, Okunbor and Obaretin examined the effectiveness of the application of forensic accounting services in deterring fraudulent activities among corporate organizations in Nigeria. To achieve the objective of this study, data was collected from the primary source. The primary data was collected through the administration of well-structured and tailored questionnaires to ten companies quoted on the Nigeria stock exchange ranging from banking, insurance, petroleum, food \& beverages, and brewing subsectors of the economy. The simple regression method was used to analyze the data collected. Findings revealed that the application of forensic accounting services by corporate organizations in Nigeria is not effective in deterring fraudulent activities. The study therefore recommended that organizations should ensure o formulate good personnel and recruitment policies attracting high salary as the remedy for fraud. It was also recommended that the management should adopt better accounting systems sound in principle and practice.

Using the primary data collected through well structure questionnaires administered to twenty four banks in Port Harcourt, Rivers state of Nigeria, a linear model was estimated by Onuorah et al. [31]. To examine the effect of forensic accounting services on fraud detection in Nigerian banks. To achieve the objective of this study, the data collected was analyzed using descriptive statistics, Augmented Dickey Fuller test, Ordinary least square regression analysis and Granger Causality test. Result showed that the application of forensic accounting services significantly affect the level of fraudulent activities of banks. Based on this finding, the study concluded that forensic accounting services offer banks the desired tools to deter fraudulent activities. The study therefore recommended that regulatory authorities should ensure to provide standard and guidelines to regulate forensic activities.

Further researches were conducted by Adegbie et al. [32]; and Okoli and Gbegi to investigate forensic accounting as an antidote for detecting economic and financial crime in Nigeria. Adegbie et al. [32] in their study adjudged that corruption and other financial and economic crimes are the bane of Nigeria development efforts. 
The study is empirical and descriptive in nature with its population being government parastatals in which 100 questionnaires were distributed to them. The study discovered:

a. Forensic accounting will provide litigation support service with appropriate of professional services in the law courts

b. Forensic accounting will institute good corporate governance in public sector which will instill public confidence in the government and the entire system,

c. The image of Nigeria in the international community has discouraged foreign direct investment because of economic and financial crime.

This has effect on the development, employment and the standard of living of the people. The study therefore recommended eradication of economic and financial crime through the adoptions of forensic accounting in the system which will improve the image of Nigeria. Crime free environment will attract foreign direct investment. The study however filled the gap created in the resolution to financial crime in Nigeria. Among the contributions to knowledge were that forensic accounting should be taught as a compulsory course in all Nigerian universities and the government should enact a law making forensic accounting a practice in Nigeria [33].

Okoli and Gbegi examined the role of forensic accounting as a tool for fraud detection and prevention in the public sector organizations, giving reference to Kogi state in Nigeria. The study employed the primary and secondary data for analysis. The primary data was collected through the administration of 370 questionnaires to staff of five selected ministries in Kogi state. To achieve the objective of the study, tables, simple percentages and the analysis of variance (ANOVA) statistical tools was used to analyze the data. The result showed that forensic accounting significantly reduced the occurrence of fraud cases in the public sector. The study concluded that the use of forensic accounting services can help to improve detection and prevention of fraud in public organizations. The study therefore recommended that the external auditors across ministries in Kogi state should be replaced with forensic accountants while proper training and consequent retraining on forensic accounting should be provided to all staff of Kogi state.

While results have shown the effectiveness of the application of forensic accounting services in deterring fraudulent activities across organizations in Nigeria, the result of Okunbor and Obaretin has been inconsistent with findings. Eme, Inyang and Udeme therefore investigated the effectiveness of the mechanisms of fraud prevention and detection in Nigeria. To achieve this objective of the study, data was collected from accounting practitioners in Nigeria through the use of the survey instrument, questionnaires. The result found internal controls, operational audits, and corporate code of audit, forensic accounting techniques and many other fraud prevention and detection mechanisms used in Nigeria. Result of the study however revealed that the most effective mechanism is the forensic accounting technique, although the least used in Nigeria The study concludes that the popularly used prevention and detection techniques used recently in Nigeria are not proactive in putting an end to fraud hazards. The study therefore recommended that the forensic accounting technique, the most proactive mechanism should be adopted [34].

\section{Methodology}

In this study, the survey design was used as this type of research design aids the collection of large amount of data from a sizable population in a highly economical way. This research design is critical in determining the quality of research as it helps in addressing the study's research questions. The population size for the purpose of this study is the 21 money deposit banks in Nigeria. According to Balsely and Clover " $10 \%$ of the population is sufficient to form the sample size of a study. This was furthermore corroborated by Ogolo, who argued that "In an instance where population is known, a minimum of $10 \%$ can constitute a sample size that is researchable". Bearing this in mind, four (4) deposit money banks (which is above $10 \%$ of the population) in Nigeria were selected. The study adopted the primary source of data while the questionnaire was the research instrument engaged. The questionnaire was designed using the five point likert scale and it was divided into three sections with each section comprising questions on each of the objective. Twenty-five (25) copies of the questionnaire were administered to each of the four (4) deposit money banks giving a total of 100 copies of the questionnaire administered in all. The one hundred (100) copies of the questionnaire were administered to the respondents who in this case are the accountants, auditors and member of management of these selected banks [35-37].

Validity is concerned with the extent to which an instrument measures what it is supposed to measure (Ofanson and Aigbokhaevbolo). For the purpose of this study, the content validity was adopted. To engage the content validity method, the questionnaire was reviewed by experts and independent assessors both within and outside the field of accounting. Following this review, corrections, suggestions and amendments were made and implemented before administering copies of the questionnaire to the selected respondents. Reliability is concerned with the stability and consistency of an instrument (Olu). To verify the reliability of the measuring instrument (questionnaire) developed for the purpose of this study, test retest reliability method was engaged. Test re-test involves measuring the same individuals at two points in time. It involves giving the same test twice. The data was summarized and presented in form of frequencies, percentages, tables and graphs. Three (3) hypotheses were formulated in this study with these hypotheses tested using Regression, T-test and One way ANOVA respectively. While the Ordinary Least Square Regression (OLS) was used to test hypothesis one, hypothesis two was on the other hand tested using T-test. Hypothesis three was however tested using the One Way Anova. The OLS technique was used to determine the relationship between the dependent variable (which is in this case fraud prevention and detection) and the 
independent variable (forensic accounting). T-test was engaged to test for the statistical difference in the mean of two groups (forensic accountants and external auditors) while the One Way Anova was engaged to determine whether there are any significant differences between the means of two or more independent (unrelated) groups. The data gathered was analyzed using Statistical Package for Social Sciences (SPSS) software.

\section{Model specification}

This research work aims at examining the role of forensic accounting in fraud prevention and detection in the Nigeria banking industry in an ordinary least square regression framework.

Mathematically, model is specified as follows:

$Y=F(X)$

Where:

Y=Dependent variable $=$ Fraud

$\mathrm{X}=$ Independent variable=Forensic accounting comprising Fraud investigation, Expert consultancy and Litigation Support.

$X=f\left(x_{1}, x_{2}, x_{3} \ldots \ldots \ldots x_{n}\right)$

Where:

$$
\begin{aligned}
& x_{1}=\text { Fraud investigation } \\
& x_{2}=\text { Expert consultancy } \\
& x_{3}=\text { Litigation support } \\
& \mu=\text { Error term } .
\end{aligned}
$$

The full specification of the regression equation is as stated below:

Fraud $=\beta_{0}+\beta_{1}$ Fraud $I+\beta_{2}$ Expect $C+\beta_{3}$ Litigation $S+\mu_{t}$

Where:

$\mathrm{F}=$ Fraud

Fraud I= Fraud Investigation

Expert C= Expert consultancy

Litigation S= Litigation Support

Forensic accounting $=\beta_{0}+\beta_{1}$ Fraud investigation $+\beta_{2}$ Expect consultancy $+\beta_{3}$ Litigation support

Where $\beta_{0}$ is the constant of the model while $\beta_{1}, \beta_{2}$, and $\beta_{3}$ , are the coefficients of the independent variables. $\mu$ is the error term.

\section{A priori expectation}

The a priori expectations are stated mathematically below:

With regards to fraud investigation, it is expected that fraud investigation (a component of forensic accounting) will be inversely related to fraud. That is, an increase in fraud investigation will lead to a decrease in fraud. Therefore, the a priori expectation, which is otherwise known as the expected sign of the coefficient of Fraud investigation from our model specified in section 3.8 above, $\beta_{1}$, is as below:

$$
\beta 1=\frac{\partial F}{\partial F I}<0
$$

With regards to expect consultancy it is expected that expert consultancy (a component of forensic accounting) will be inversely related to fraud. That is, an increase in expert consultancy will lead to a decrease in fraud. The a priori expectation, which is otherwise known as the expected sign of the coefficient of expert consultancy from our model specified in section 3.8 above, $\beta_{2}$, is as below:

$$
\beta 2=\frac{\partial F}{\partial E C}<0
$$

With regards to litigation support it is expected that litigation support (a component of forensic accounting) will be inversely related to fraud. That is, an increase in litigation support will lead to a decrease in fraud. The a priori expectation, which is otherwise known as the expected sign of the coefficient of litigation support from our model specified in section 3.8 above, $\beta 3$ is as below:

$$
\beta 3=\frac{\partial F}{\partial L S}<0
$$

\section{Results}

For the purpose of this research study, the method of analysis to be used include: Regression analysis for hypothesis one (1), T-test for Hypothesis two (2) and One way ANOVA for Hypothesis three (3).

\section{Hypothesis one}

$\mathbf{H}_{\mathbf{1}}$ : There is significant relationship between forensic accounting and fraud prevention and detection in Nigeria banking industry.

\section{Regression Analysis}

Table 1 is the model summary. It shows how much the variance in the dependent variable (fraud prevention and detection) is explained by the model. The table provided useful information about the regression analysis, the value is 0.033 which when expressed in percentage terms shows that $3.3 \%$ variation in the dependent (fraud prevention and detection) is explained by the independent variable (forensic accounting) while the remaining $96.7 \%$ variation in the dependent variable is affected by other factors not captured in this study.

Table 1: Model Summary (a) Predictors: (Constant), Forensic accounting.

\begin{tabular}{|c|c|c|c|c|}
\hline Model & $\mathbf{R}$ & R Square & $\begin{array}{c}\text { Adjusted R } \\
\text { Square }\end{array}$ & $\begin{array}{c}\text { Std. Error of the } \\
\text { Estimate }\end{array}$ \\
\hline 1 & $.182(\mathrm{a})$ & .033 & .023 & 1.045 \\
\hline
\end{tabular}

\section{Anova}

Table 2 reflects the overall model fit and the statistical significant of the result. The significant value of 0.071 reflects that there is a significant relationship between the independent variable being forensic accounting and dependent variable being fraud prevention and detection. An " $F$ " value of 3.339 indicates that the model is fit for the test of hypothesis. 
Table 2: ANOVA (b)

(a)Predictors: (Constant), Forensic accounting

(b) Dependent Variable: Forensic accountants in Nigeria banks are best suited to addressing fraud detection and prevention.

\begin{tabular}{|c|c|c|c|c|c|c|}
\hline Model & & Sum of Squares & Df & Mean Square & F & Sig. \\
\hline 1 & Regression & 3.649 & 1 & 3.649 & 3.339 & $.071(\mathrm{a})$ \\
\hline & Residual & 107.101 & 98 & 1.093 & & \\
\hline & Total & 110.750 & 99 & & & \\
\hline
\end{tabular}

\section{Coefficients}

The coefficient table confirms the fact that forensic accounting has a significant impact on fraud prevention and detection. This

Table 3: Coefficients (a)

(a)Dependent Variable: Forensic accountants in Nigeria banks are best suited to addressing fraud detection and prevention.

\begin{tabular}{|c|c|c|c|c|c|c|}
\hline \multirow{2}{*}{ Mode 1 } & \multicolumn{2}{|c|}{ Unstandardized Coefficients } & $\begin{array}{c}\text { Standardized } \\
\text { Coefficients }\end{array}$ & T & Sig. \\
\cline { 3 - 7 } & & B & Std. Error & Beta & Std. Error \\
\hline $\begin{array}{c}\text { Forensic } \\
\text { accounting }\end{array}$ & (Constant) & 1.229 & 1.220 & .182 & 1.007 & .316 \\
\end{tabular}

\section{Hypothesis Two}

$\mathbf{H}_{\mathbf{1}}$ : There is significant difference in the role forensic accounting and external auditors in the detection and prevention of fraud.

The t-test value is the estimated number of standard errors between the two means. The result of Levene's test for equality Table 4: Independent Samples Test Source: Field Survey (2018). is depicted with a significant value of 0.071 -Beta value of 0.182 reveals that a change in the independent variable (forensic accounting) results in $18.2 \%$ changes in the dependent variable (fraud prevention and detection) (Table 3) of variance test whether or not the variances of scores of result in the two groups are the same. Based on the table above, the "equal variance assumed" was used in arriving at the result. This was as a result of having a significant value of 0.204 which is higher than the cut-off value/rate of $(p<0.05)$ (Table 4$)$

\begin{tabular}{|c|c|c|c|c|c|c|c|c|c|c|}
\hline \multicolumn{2}{|c|}{} & \multicolumn{2}{|c|}{$\begin{array}{c}\text { Levene's Test for Equality } \\
\text { of Variances }\end{array}$} & \multicolumn{5}{|c|}{ T-test for Equality of Means } \\
\cline { 2 - 11 } & F & Sig. & T & Df & $\begin{array}{c}\text { Sig. } \\
\text { (2-tailed) }\end{array}$ & $\begin{array}{c}\text { Mean } \\
\text { Difference }\end{array}$ & $\begin{array}{c}\text { Std. Error } \\
\text { Difference }\end{array}$ & $\begin{array}{c}\text { 95\% Confidence Interval of the } \\
\text { Difference }\end{array}$ \\
\hline Fraud & $\begin{array}{c}\text { Equal } \\
\text { variances } \\
\text { assumes }\end{array}$ & 1.615 & 0.208 & 0.017 & 77 & 0.986 & 0.00204 & 0.11706 & -0.2311 & 0.23514 \\
\hline $\begin{array}{c}\text { Equal } \\
\text { variances } \\
\text { not } \\
\text { assumes }\end{array}$ & Lower & Upper & Lower & Upper & Lower & Upper & Lower & Upper & Lower \\
\hline
\end{tabular}

Using the equal variance assumed, under the t-test for equality of means assumed, the significant value (2-tailed) used was 0.986 which is greater than the cut-off of 0.05 . Hence, the alternative hypothesis was rejected while the null hypothesis was accepted. Therefore, based on the analysis above, the result showed that there is no significant difference in the role of forensic accountants and external auditors in the prevention and detection of fraud.

\section{Hypothesis Three}

$\mathbf{H}_{1}$ : Forensic accounting has a high level of awareness in prevention and detection of fraud in the Nigeria banking industry.

\section{One-way ANOVA}

I am aware of the role of forensic accountants in banks

The table above shows the output of the ANOVA, and whether there is a statistical difference between our group means. From the result above it shows that the significant level is $0.338(\mathrm{p}=0.338)$, which is below 0.05 and concluded that there is no statistical significant difference between the means. Therefore there is a low level of the awareness of forensic accounting in the Nigeria banking industry. The reason for this is as a result of the fact that most 
accountants, auditors and managers are not aware of the role of forensic accounting in the Nigeria banking industry (Table 5).

Table 5: One-Way ANOVA Source: Field Survey (2015).

\begin{tabular}{|c|c|c|c|c|c|}
\hline & $\begin{array}{c}\text { Sum of } \\
\text { Squares }\end{array}$ & Df & $\begin{array}{c}\text { Mean } \\
\text { Square }\end{array}$ & F & Sig. \\
\hline $\begin{array}{c}\text { Between } \\
\text { Groups }\end{array}$ & 8.654 & 11 & .787 & 1.144 & .338 \\
\hline $\begin{array}{c}\text { Within } \\
\text { Groups }\end{array}$ & 60.506 & 88 & .688 & & \\
\hline Total & 69.160 & 99 & & & \\
\hline
\end{tabular}

\section{Conclusion and Recommendations}

\section{Conclusion}

From the discussion, the researcher presumes that banks in Nigeria have adopted various forensic accounting practices which include litigation support, fraud investigation, and expert consultancy. The study further more ascertains that there is a positive impact of forensic accounting on fraud prevention and detection. A firm wishing to grow with minimized level of fraud must therefore put into place sufficient resources to be able to properly practice forensic accounting in its different departments. Just as money deposit banks use other means of reducing the occurrence of fraud, forensic accounting can provide confidence in financial statements as it has a positive impact on fraud prevention and detection. Among legal strategies utilized in different organizations, personal responsibility has emerged as one of the most preferred strategies of curbing fraud. Therefore, in order to sustain effective operations in the bank, fraudulent activities must be monitored, prevented and detected in the banking sector with forensic accounting being a tool that can be used to aid this.

\section{Recommendations}

In view of the findings of this study, the following recommendations are proffered:

1. Government should provide the enabling environment for forensic accounting profession to thrive in the country by strengthening the legal, educational and political frame work in the country (Nigeria).

2. The National Universities Commission (NUC) should ensure that forensic accounting techniques are included in the curriculum for the training of undergraduate students of accounting in Nigeria universities.

3. Universities should encourage specialization in forensic accounting techniques at the post-graduate level.

4. The Institute of Chartered Accountants of Nigeria (ICAN) and other regulatory bodies should include forensic accounting in their curriculum of their professional examination.

5. Accounting practitioners should be aware of the benefits of forensic accounting in preventing and detecting fraud in their establishments and they should be aware of the severity of financial fraud and the susceptibility of their organizations to fraud.

6. Organizations should incorporate the use of accounting and prevention and detection of fraud so as to reduce the cases of fraud and financial misappropriation.

\section{References}

1. Alex E (2012) The role of banks in capital formation and economic growth. Economy trans disciplinary cognition 15(1): 103-111.

2. Adeyemo K (2012) Frauds In Nigerian Banks: Nature, Deep-Seated causes, Aftermaths and Probable Remedies. Mediterranean Journal of Social Sciences 3(2): 79-80.

3. (2010) Association of Certified Fraud Examiner (ACFA). Report to the nation on occupational fraud and abuse.

4. Crumbley D, Heitger L, Smith G (2009) Forensic an investigative accounting .The ABO Reporter Fall 9: 3-5.

5. Friedlop G, Plewa F (1996) Understanding balance sheets. New York: John Wiley \& Sons.

6. Kasum A (2009) The Relevance of Forensic Accounting to Financial Crimes in Private and Public Sectors Of Third World Economies: A Study From Nigeria. The 1st International Conference on Governance Fraud Ethics and Social Responsibility p.11-13

7. Crumbley D (2003) Certified forensic accountant. American college of forensic examiners international. Online posting.

8. Bologna G, Lindquist R (1987) Fraud auditing and forensic accounting: New tools and techniques. New Jersey: Wiley Publishers.

9. Zysman A (2004) Forensic accounting demystified, world investigators network standard practice for investigative and forensic accounting engagements.

10. Joshi M (2003) Definition of forensic accounting.

11. Mehta G, Mathur T (2007) Preventing financial fraud through forensic accounting. The Chartered Accountant 1575-1580.

12. Crumbley D (2001) Forensic Accounting: Older than you think. Journal of Forensic Accounting 2(2): 181-202.

13. Coenen T (2005) Forensic accounting, a new twist on bean counting.

14. Evazzadeh H, Ramazani M (2012) Accountants' perception of forensic accounting (case study of Iran). Global Journal of Management and Business Research 12(6): 1-5

15. Krstić J (2009) The role of forensic accountants in detecting frauds in financial statements. Economic and Organization

6(3): 295-302

16. Crumbley D (2003) What is forensic accounting?

17. Mckittrick C (2009) Forensic accounting-it's broader than you think and can help your organization. Forensic Accounting 1(1): 3.

18. Adewal A (2008) Fraud in banks: The Nigerian perspective. A paper presented at Expert edge Software - Seminar on fighting fraud with technology: Solutions to Nigerian banks.

19. Robertson J (1976) Fraud awareness auditing. In: Richard D (Ed.), Irwin Chicago, USA

20. Stanley B (1994) International fraud. New York: McGraw Hill.

21. Özkul S, Pamuku A (2012) Fraud detection and forensic accounting. In: Cahyurt K, Idowu S (Eds.), Emerging fraud, Springer-Verleg Berlin Heidlberg, p. 19-41. 
22. (2008) Association of Certified Fraud Examiners. Report to the nation on occupational fraud abuse. Austine: Tax Association of Certified Fraud Examiners.

23. Udoayang J, James F (2004) Auditing and investigation. University of Calabar Press, Calabar, Nigeria.

24. Ramamoorti S, Olsen W (2007) Fraud: The human factor. Financial Executive, pp. 53-55.

25. Ojo, Adewanmi (1982) Banking and finance in Nigeria. Lagos: CIBN \& Landmark publication Limited.

26. Hamilton D, Gabriel J (2012) Dimensions of fraud in Nigeria quoted firms. Am J Soc Mgmt Sci 3(3): 112-120.

27. Sydney I (1986) Management control system and the prevention and detection of frauds in banks. Lagos: CIBN \& Landmark Publications Limited.

28. Ojigbede S (1986) Fraud in banks. An unpublished paper presented at an effective Bank inspectors course organized by FITC in Lagos.

29. (2002) International Standards for Professional Practice of Internal Auditing. Report of International Standards for Professional Practice of Internal Auditing Florida: The Institute of Internal Auditors.

30. Silverstone H, Sheetz M (2007) Forensic accounting and fraud investigation for non-experts $\left(2^{\text {nd }}\right.$ edn). In: John Wiley \& Sons (Eds.), New Jersey, USA.
31. Ebimobowei A, Onuorah Anastasia Chi-Chi (2012) Fraudulent activities and forensic accounting services of banks in Port Harcourt, Nigeria. Asian Journal of Business Management 4(2): 124-129.

32. Adegbie F, Fakile A (2012). Economic and financial crime in Nigeria: Forensic accounting as antidote. British Journal of Arts and Social Science 6(1): 39-41.

33. Adefila J, Kasum A, Olaniyi T (2005) The global endemic nature of financial malpractices: an analytical appraisal. African Journal of Management 1(1): 11-22.

34. (2006) AICPA Audit risk exposure standards. Statements of Auditing Standard.

35. Evazzadez H, Ramazani M (2012) Accountants perception of forensic accounting (case study of Iran). Global Journal of Management and Business Research 12(6): 1-5

36. Pedhazur E (1997) Multiple regressions in behavioral research: explanation and prediction. ( $3^{\text {rd }}$ edn) New York, Harcourt Brace College, USA

37. Okoye E (2010) Forensic Accounting: A Tool for Fraud Detection and Prevention in Public Sector. (A study of selected ministries in Kogi State) $3(3)$.
Creative Commons Attribution 4.0 International License

For possible submissions Click Here

\section{Submit Article}

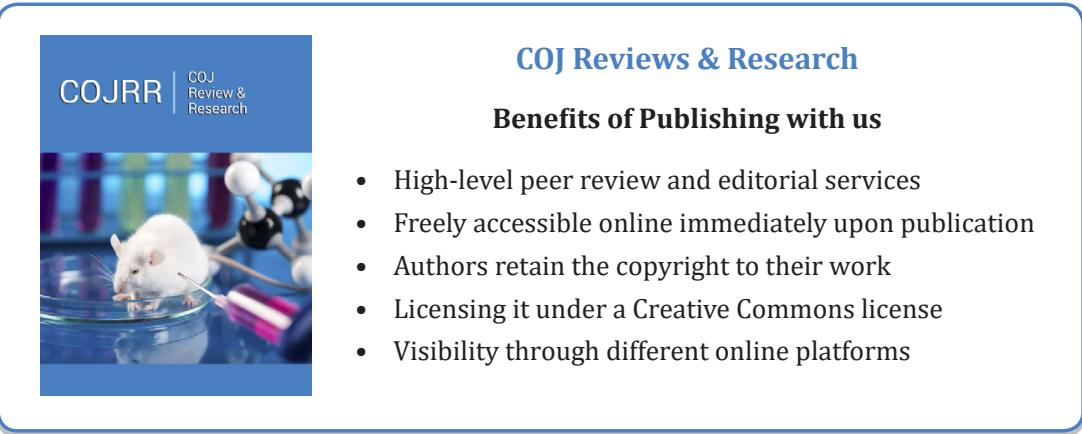

